\title{
Application of GIS Models in Site selection of waste disposal in Urban Area
}

\author{
H. Shahabi ${ }^{1}$, H. Allahvirdiasl ${ }^{2}$, Mr.Mohsen Ali zadeh ${ }^{3}$ \\ ${ }^{1,2}$ Department of Remote sensing, Faculty of Geo Information and Real Estate, universiti Teknologi \\ Malaysia (UTM), 81310 Johor Bahru, Johor, Malaysia \\ ${ }^{3}$ Department of Urban and Regional Planning, Faculty of Built Environment, Universiti Teknologi \\ Malaysia (UTM), 81310, UTM Johor Bahru, Johor, Malaysia
}

\begin{abstract}
Landfill siting should take into account a wide range of territorial and legal factors in order to reduce negative impacts on the environment. The suitability of selected site for disposal center affects the amount of generated energy and the cost of disposal generation. Suitable sites should be determined on the basis of technical, economical and socio-environmental issues. GIS along with appropriate models and spatial analysis method can be used to define the suitability of different locations for the construction of disposal centers. This research focused on determining suitable locations for construction of a suitable disposal centers. Our study area is Saqqez city in Kurdistan province in North West of Iran. At the first, important parameters in hazardous material disposal center sitting for studied area were identified. Then, the maps of studied area were prepared and integrated. Boolean, index overlay, and fuzzy logic models were used for integrating of maps. The suitable locations for the waste material disposal center were selected using each model. Finally, in index overlay and fuzzy logic model, $0.12 \%$ and $0.17 \%$ of the study area was selected as suitable, respectively. In both of the methods, the majority of suitable area was located in south east of city, where waste demand is more than other places.
\end{abstract}

Keywords- Waste disposal; Site selection; GIS; Saqqez city.

\section{Introduction}

The components of municipal solid waste (MSW) management include reducing the waste, reusing, recycling, energy recovery, incineration and landfilling [10]. Even if a combination of the mentioned or other management techniques is utilized and if policies of waste reduction and reuse are applied, the existence of a sanitary landfill is necessary to a MSW management system [11]. Decision and policy making based on detailed information as well as modeling for solving various environmental and ecological problems (e.g., siting MSW landfill) seem necessary [12]. Regarding the problems related to making decisions on (e.g., siting landfill with multi criteria), it can be said that decision making is not simple in this case, and the speed and precision are greatly reduced due to the lack of standards [9]. In Iran, the waste demand has grown rapidly over the past years. A demand study for the country shows the need for new capacity to meet the growing wastes. Therefore, it's necessary to selection of new disposal centers. One of the most important factors, which should be considered in new disposal center construction process, is the location of the disposal center [13]. The suitability of selected site for disposal center affects the amount of generated waste and the cost of transmission. Suitable sites should be determined on the basis of technical, economical and socio-environmental issues and meet multiple criteria. GIS along with appropriate models and spatial analysis method can be used to define the suitability of different locations for the construction of disposal centers. In this paper, the required conditions for the establishment of disposal centers are comprehensively studied for Saqqez city in Kurdistan province in north west of Iran. Then, important parameters in disposal center are identified. Later the factor maps of studied area was prepared and integrated. There are several map combination processes; these are Boolean logic combination, algebraic combination, and index overlay combination, fuzzy logic and vector fuzzy logic combinations, and so on. In this project, Boolean, index overlay, and fuzzy logic models were used for integrating of maps. Finally the suitable locations for the construction of disposal center are selected.

\section{Material and Methods}

2.1. Study area and datasets

Prediction of the waste consumption for the coming years shows the necessity for a new disposal center establishment in Saqqez city in Kurdistan province. At the 2006 census, the city's population was 135037, whereas its current population is about 143000 . The vegetation density city was 118 hectare. Building area was 618.26 hectare. The average elevation of the city is about 1496 meters above mean sea level. Saqqez is characterized as a mountainous area which is located within Zagros Mountains rages from south-east to north- 
west. This area comprises about 15.5 percent of Kurdistan province. The difference of height between the highest elevation point (Chehel-Cheshme mountain, $3173 \mathrm{~m}$ and Simineh-Rood basin, $1150 \mathrm{~m}$ above mean sea level) is about $2023 \mathrm{~m}$ [13]. Saqqez river (Chom Saqqez) emanates from western mountains (Gardaneh Khan) and continues its path across the city toward north-east. Considering the available spatial data in the study area, the data layers of scale 1:250,000 were used in this project (Fig. 1).

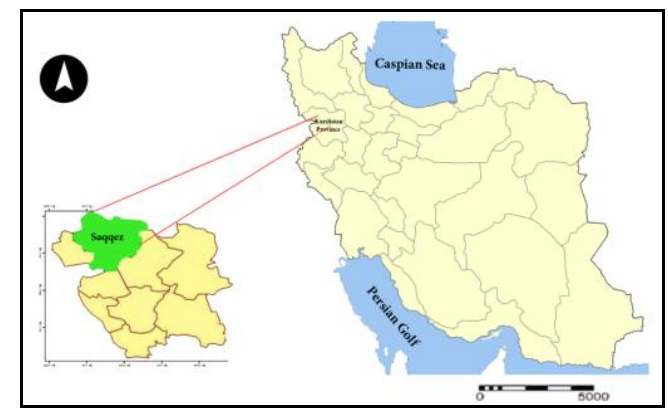

Fig. 1. Location of Study Area in Kurdistan province in Iran

Table 1 illustrates several data layers which have been used in this study.

Table1. data layers used in this study

\begin{tabular}{|c|c|c|}
\hline & \multicolumn{2}{|c|}{ Data layers } \\
\hline Elevation & Suitable & Protected area \\
\hline Slope & area & River \\
\hline Fault & precipitation & City \\
\hline Earthquake spots & Orchard & Village \\
\hline land use & Floodplain & Road \\
\hline Litho $\log y$ & Under ground water & power pipe line \\
\hline
\end{tabular}

Direction of dominant wind and direction of city development show was in fig. 2.

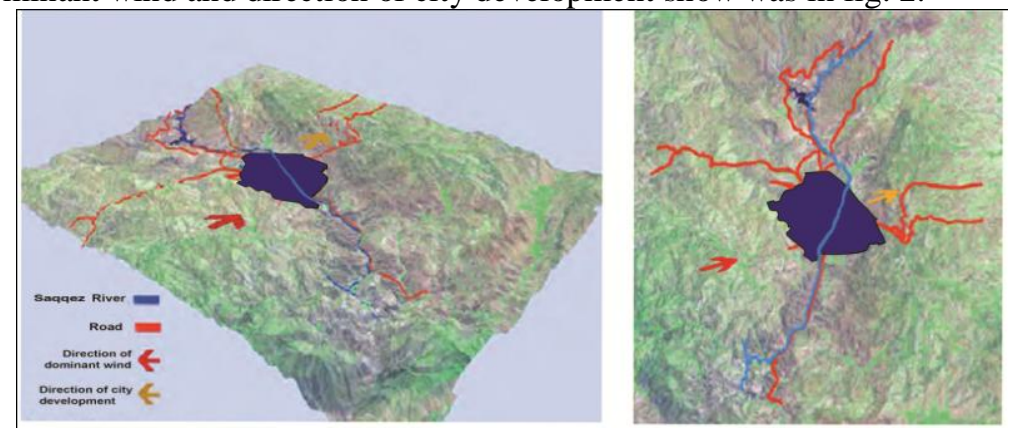

Fig. 2.Three dimensional model (3D) of saqqez city

\subsection{Maps Generation and Data integration}

Considering the mentioned layers, according to the characteristics of factors and their effect on disposal center sitting, two different types of maps were generated: limitation maps and factor maps.

\subsubsection{Limitation maps}

Such a map defines the area that cannot be used for the disposal center because of a limiting factor. As the purpose of creating such a map is to completely exclude the unsuitable areas, it can be a binary map, in which the areas with limiting condition (not suitable) are given the value of zero and the allowed (suitable) areas are given the value of one. These maps are overlaid using the Boolean Operation (fig. 3), where input maps can be integrated by using logical operators such as AND, OR, XOR and NOT [1]. 


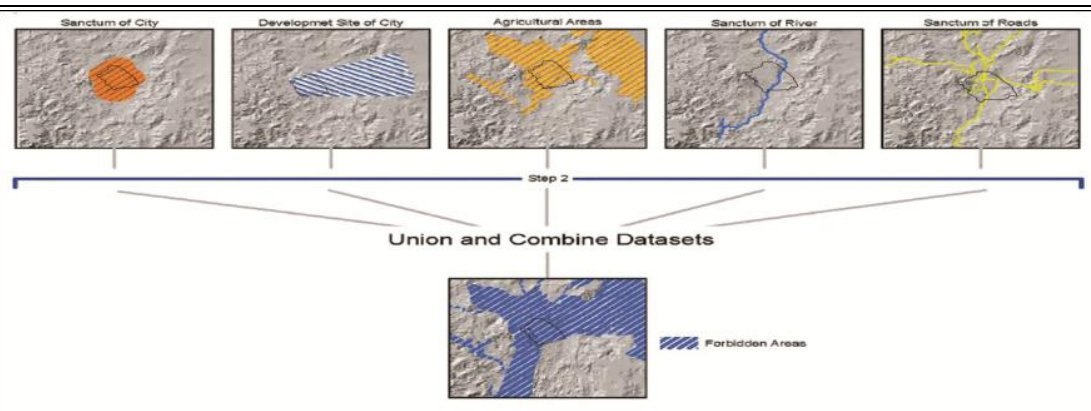

Fig. 3. Diagram of Booleans Method establish stages

In this research logical 'AND' operator was used, which resulted in the selection of areas that have 'one' value in all binary maps. The list and criteria for generation of such maps is presented in table 2 .

Table 2. Limitation maps and their criteria

\begin{tabular}{|c|c|c|c|c|c|}
\hline $\begin{array}{l}\text { Feat } \\
\text { ure }\end{array}$ & $\begin{array}{l}\text { Descri } \\
\text { ption }\end{array}$ & $\begin{array}{l}\text { Limi } \\
\text { tation or buffer } \\
\text { size }\end{array}$ & Feature & Description & $\begin{array}{l}\text { Limitatio } \\
\mathrm{n} \text { or buffer size }\end{array}$ \\
\hline $\begin{array}{l}\text { Elev } \\
\text { ation }\end{array}$ & - & $\begin{array}{l}>200 \\
0 \mathrm{~m}\end{array}$ & lit logy & Sandy land & $\begin{array}{l}\text { The } \\
\text { whole area }\end{array}$ \\
\hline Slop & - & $\begin{array}{l}>15 \\
\%\end{array}$ & \multirow[t]{4}{*}{ Floodplain } & \multirow[t]{4}{*}{ - } & \multirow[t]{4}{*}{$>5 \mathrm{~km}$} \\
\hline \multirow{3}{*}{$\begin{array}{l}\text { Faul } \\
t\end{array}$} & major & $\begin{array}{l}>5 \mathrm{k} \\
\mathrm{m}\end{array}$ & & & \\
\hline & minor & $\begin{array}{l}>1 \mathrm{k} \\
\mathrm{m}\end{array}$ & & & \\
\hline & reverse & $\begin{array}{l}>2 \mathrm{k} \\
\mathrm{m}\end{array}$ & & & \\
\hline \multirow[t]{2}{*}{$\begin{array}{l}\text { Eart } \\
\text { hquake spots }\end{array}$} & $\begin{array}{l}5.5-6 \\
\mathrm{mb}\end{array}$ & $1 \mathrm{~km}$ & \multirow[t]{2}{*}{ Orchard } & & \multirow[t]{2}{*}{$\begin{array}{l}\text { The } \\
\text { whole area }\end{array}$} \\
\hline & $>6 \mathrm{mb}$ & $2 \mathrm{~km}$ & & & \\
\hline \multirow[t]{2}{*}{ City } & $\begin{array}{l}\text { Large } \\
\text { city }\end{array}$ & $\begin{array}{l}20 \mathrm{k} \\
\mathrm{m}\end{array}$ & \multirow{3}{*}{$\begin{array}{l}\text { Protected } \\
\text { area }\end{array}$} & $\begin{array}{l}\text { National } \\
\text { park }\end{array}$ & $>10 \mathrm{~km}$ \\
\hline & $\begin{array}{l}\text { Mediu } \\
\text { m city }\end{array}$ & $\begin{array}{l}10 \\
\mathrm{~km}\end{array}$ & & Wild life & $>10 \mathrm{~km}$ \\
\hline $\begin{array}{l}\text { Vill } \\
\text { age }\end{array}$ & - & $2 \mathrm{~km}$ & & protected & $>10 \mathrm{~km}$ \\
\hline \multirow{2}{*}{$\begin{array}{l}\text { Suit } \\
\text { able area }\end{array}$} & \multirow[t]{2}{*}{-} & & \multirow{3}{*}{ River } & major & $>2 \mathrm{~km}$ \\
\hline & & hec & & minor & $>250 \mathrm{~m}$ \\
\hline \multirow[t]{2}{*}{ road } & \multirow[t]{2}{*}{-} & \multirow[b]{2}{*}{$\begin{array}{l}>2 \mathrm{k} \\
\mathrm{m}\end{array}$} & & & \\
\hline & & & land use & cultivated & $\begin{array}{l}\text { The } \\
\text { whole area }\end{array}$ \\
\hline $\begin{array}{l}\text { Pow } \\
\text { er pipe lines }\end{array}$ & - & $\begin{array}{l}> \\
1 \mathrm{~km}\end{array}$ & \multirow[t]{2}{*}{ precipitation } & \multirow[t]{2}{*}{-} & \multirow[t]{2}{*}{$>450 \mathrm{~mm}$} \\
\hline $\begin{array}{l}\text { Und } \\
\text { er ground water }\end{array}$ & - & $\begin{array}{l}>40 \\
\mathrm{~m}\end{array}$ & & & \\
\hline
\end{tabular}

\subsubsection{Factor maps}

Some of the parameters do not affect the suitability of a location in an absolute manner (e.g. making it absolutely unsuitable), yet has a positive or negative effect on the suitability. In a factor map, areas can be given different weights according to their suitability for disposal center locating [2]. For example one of the most important criteria that should be considered in disposal center sitting, is proximity to the roads. Therefore, in road factor map, values are decreasing when the distance from road is increased. For each of these parameters a factor map was created (See Table 3).

Table 3. Factor maps and their classes

\begin{tabular}{|c|c|c|c|c|c|}
\hline Factor & $\begin{array}{l}\mathrm{Cl} \\
\text { ass of Factor }\end{array}$ & $\begin{array}{l}\text { Weight } \\
\text { of class }\end{array}$ & Factor & $\begin{array}{l}\text { Class of } \\
\text { Factor }\end{array}$ & $\begin{array}{c}\text { W } \\
\begin{array}{c}\text { eight of } \\
\text { class }\end{array}\end{array}$ \\
\hline \multirow{3}{*}{ Elevation } & $0-1000 \mathrm{~m}$ & 0.9 & & $\begin{array}{c}\text { Alluvial } \\
\text { fans }\end{array}$ & .2 \\
\hline & $\begin{array}{l}10 \\
00-1400 \mathrm{~m}\end{array}$ & 0.8 & & $\begin{array}{c}\text { Alluvium } \\
\text { terrace }\end{array}$ & 0 \\
\hline & 14 & 0.4 & & & \\
\hline
\end{tabular}


Application of GIS Models in Site selection of waste disposal in Urban Area

\begin{tabular}{|c|c|c|c|c|c|}
\hline & 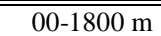 & \multirow[b]{2}{*}{0.1} & \multirow{12}{*}{$\begin{array}{l}\text { Gology } \\
\text { and Soil type }\end{array}$} & \multirow{2}{*}{$\begin{array}{l}\text { Igneous } \\
\text { rocks }\end{array}$} & \multirow[b]{2}{*}{.9} \\
\hline & $\begin{array}{ll}>1 & \\
& 800\end{array}$ & & & & \\
\hline \multirow{3}{*}{ Slope } & $\begin{array}{ll}0 . & \\
& 6 \% \\
\end{array}$ & 0.9 & & $\begin{array}{l}\text { Karstic } \\
\quad \text { limestone }\end{array}$ & $\begin{array}{ll}0 & \\
& .8 \\
\end{array}$ \\
\hline & 6- $10 \%$ & 0.7 & & $\begin{array}{l}\text { Lagoon and } \\
\text { Salt bottoms }\end{array}$ & $\begin{array}{ll}0 & \\
& .1 \\
\end{array}$ \\
\hline & $\begin{array}{ll}>1 & \\
& 0 \% \\
\end{array}$ & 0.1 & & Limestone & 0 \\
\hline & $0.5-10 \mathrm{~km}$ & 0.9 & & $\begin{array}{l}\text { Lower } \\
\text { alluvium terrace }\end{array}$ & $\begin{array}{ll}0 & \\
& .2 \\
\end{array}$ \\
\hline & $\begin{array}{l}10 \\
-20 \mathrm{~km}\end{array}$ & 0.7 & & $\begin{array}{l}\text { Lower } \\
\text { plain alluvium }\end{array}$ & $\begin{array}{ll}0 & \\
& .2 \\
\end{array}$ \\
\hline Road & $20-40 \mathrm{~km}$ & 0.3 & & Marl & $\begin{array}{lll}0 & & \\
& 4\end{array}$ \\
\hline & $>4 \quad 0 \mathrm{~km}$ & 0.1 & & $\begin{array}{l}\text { Marl, } \\
\text { Shale, Schist }\end{array}$ & $\begin{array}{ll}0 & \\
& .4 \\
\end{array}$ \\
\hline & $\mathrm{Hi}_{\mathrm{gh}}$ & 0.9 & & Sandstone & $\begin{array}{ll}0 & \\
& .3\end{array}$ \\
\hline Demand of & $\begin{array}{ll}\text { M } & \\
& \text { edium } \\
\end{array}$ & 0.6 & & Tuff & $\begin{array}{ll}0 & \\
& .3 \\
\end{array}$ \\
\hline & $\begin{array}{ll}\text { Lo } & \\
& \mathrm{w} \\
\end{array}$ & 0.3 & & $\begin{array}{l}\text { Tuffeous } \\
\text { conglomera }\end{array}$ & $\begin{array}{ll}0 & \\
& .3 \\
\end{array}$ \\
\hline & 0- $500 \mathrm{~m}$ & 0.1 & & & \\
\hline & $\begin{array}{l}0 . \\
5-5 \mathrm{~km}\end{array}$ & 0.9 & & Excellent & $\begin{array}{ll}0 & \\
& .9 \\
\end{array}$ \\
\hline & $5-10 \mathrm{~km}$ & 0.8 & & $\begin{array}{l}\text { Mostly } \\
\quad \text { Excellent }\end{array}$ & $\begin{array}{ll}0 & \\
& .8\end{array}$ \\
\hline Gas pipe line & 10 $-20 \mathrm{~km}$ & 0.6 & & Very Good & $\begin{array}{ll}0 & \\
& .7\end{array}$ \\
\hline & 20 & 0.3 & & Good & 0 \\
\hline & $>4 \quad 0 \mathrm{~km}$ & 0.1 & & $\begin{array}{r}\text { Relatively } \\
\text { Good }\end{array}$ & $\begin{array}{ll}0 & \\
& .5 \\
\end{array}$ \\
\hline & 0- $500 \mathrm{~m}$ & 0.1 & Discharge & Medium & 0 \\
\hline & $\begin{array}{l}0 . \\
5-10 \mathrm{~km}\end{array}$ & 0.9 & & Small & .2 \\
\hline River & $\begin{array}{l}10 \\
-20 \mathrm{~km} \\
\end{array}$ & 0.1 & & Poor & $\begin{array}{ll}0 & \\
& .1 \\
\end{array}$ \\
\hline & $>2$ $0 \mathrm{~km}$ & 0.1 & & Very poor & $\begin{array}{ll}0 & \\
& .1 \\
\end{array}$ \\
\hline
\end{tabular}

On the other hand, the effects of these parameters aren't the same in the disposal center sitting. In this study, factor weights are defined to describe the significance of each parameter in the selection of proper location for combined cycle disposal centers. The importance of factors are listed in Table 4. Index Overlay and fuzzy logic model were used for factor maps combination.

Table 4. Factors and their relative importance

\begin{tabular}{|c|c|}
\hline Factor & Score of factor \\
\hline waste demand & 20 \\
\hline Protected area & 15 \\
\hline Road & 12 \\
\hline Elevation & 12 \\
\hline Slope & 8 \\
\hline Geology & 8 \\
\hline Land use & 6 \\
\hline Water Discharge & 8 \\
\hline River & 6 \\
\hline
\end{tabular}

2.3. Methods

2.3.1.Index Overlay

The following Equation was used for integration of factor maps using index overlay method.

$S=\frac{\sum W i S i j}{\sum W i}$ 
Where:

$\mathrm{Wi}=$ the weight of each factor map $\quad \mathrm{Sij}=$ the each spatial class weight of each factor map

$\mathrm{S}=$ the spatial unit value in output map

It is resulted in a map with values for every location showing different suitability of locations for disposal center construction (www.psc.wi.gov/consumerinfo/brochures/waste/6017b).

2.3.2.Fuzzy logic model

In a fuzzy map, the associated value for each pixel (Fuzzy membership value), represent both the relative importance of the factors and the relative values corresponding to different locations on the map area. Fuzzy membership values should be between zero and one. However, in this range, there is no limitation on the selection of the values. They are selected to represent the degree of membership in a set on the basis of subjective judgment. In fact, each membership value represents the suitability of the pixel area for the power station regarding to the related criteria [5]. For factor maps integration, some fuzzy operators, such as the fuzzy AND, the fuzzy OR, fuzzy algebraic product, fuzzy algebraic sum and fuzzy gamma operator can be used. A script can be written in GIS to employ this method. Five fuzzy operators can be expressed mathematically as:

$$
\begin{aligned}
& \mu_{O R}=\operatorname{MAX}\left(\mu_{A}, \mu_{B}, \mu_{C}, \ldots\right){ }_{(\text {Fuzzy OR) }} \\
& \mu_{A N D}=\operatorname{MIN}\left(\mu_{A}, \mu_{B}, \mu_{C}, \ldots . .\right) \quad \text { (Fuzzy AND) } \\
& \mu_{\text {sum }}=1-\prod_{i=1}^{n}\left(1-\mu_{i}\right) \quad \text { (Fuzzy algebraic sum) } \\
& \mu_{\text {product }}=1-\prod_{i=1}^{n} \mu_{i} \quad \text { (Fuzzy algebraic product) } \\
& \mu_{\text {combination }}=(\text { Fuzzya } \lg \text { ebraicsum })^{\lambda} *(\text { Fuzzya } \lg \text { ebraicproduct })^{1-\lambda} \quad \text { (Fuzzy gamma) } \\
& \text { Where: }
\end{aligned}
$$

$\mu \mathrm{I}$ is the fuzzy-membership function for the $\mathrm{i}$-th map, and $\mathrm{i}=1,2, \ldots, \mathrm{n}$. Output membership values are controlled by various pieces of evidence.

In the fuzzy-OR operator (Eq. (1)), the combination output membership value for any particular location is controlled by the maximum fuzzy-membership value of the input maps occurring at that location. In the fuzzy-AND operator (Eq. (2)), the output membership value for any particular location is controlled by the smallest fuzzy-membership value of the input maps occurring at that location. These operators are appropriate if the combined membership value at a location is controlled by the most suitable evidence maps. If two pieces of evidence favor a hypothesis so that the combined evidence is more supportive than one piece of evidence, then the fuzzy algebraic sum, fuzzy algebraic product, and fuzzy gamma operators are appropriate.

In the fuzzy algebraic sum (Eq. (3)), the output value is always larger than or equal to the largest contributing fuzzy-membership value. The maximum limit of the output value is 1.0. The fuzzy algebraic product is complementary to the fuzzy algebraic sum (Eq. (4)), and the output value is always smaller than or equal to the smallest contributing fuzzy-membership value. The maximum limit of the value is 1.0. The fuzzygamma operation is defined in terms of the fuzzy algebraic sum and the fuzzy algebraic product (Eq. (5)). In the fuzzy-gamma operation, when gamma is 1 , the combination is the same as the fuzzy algebraic sum, and when gamma is 0 the combination equals the fuzzy algebraic product [2]. Therefore, the appropriate choice of gamma produces output values that ensure a flexible compromise between effects of the fuzzy algebraic sum and the effects of the fuzzy algebraic product [3,7]. The selection of operator is on the basis of the characteristics of the data layers and their role in the application [6] (Fig.4).

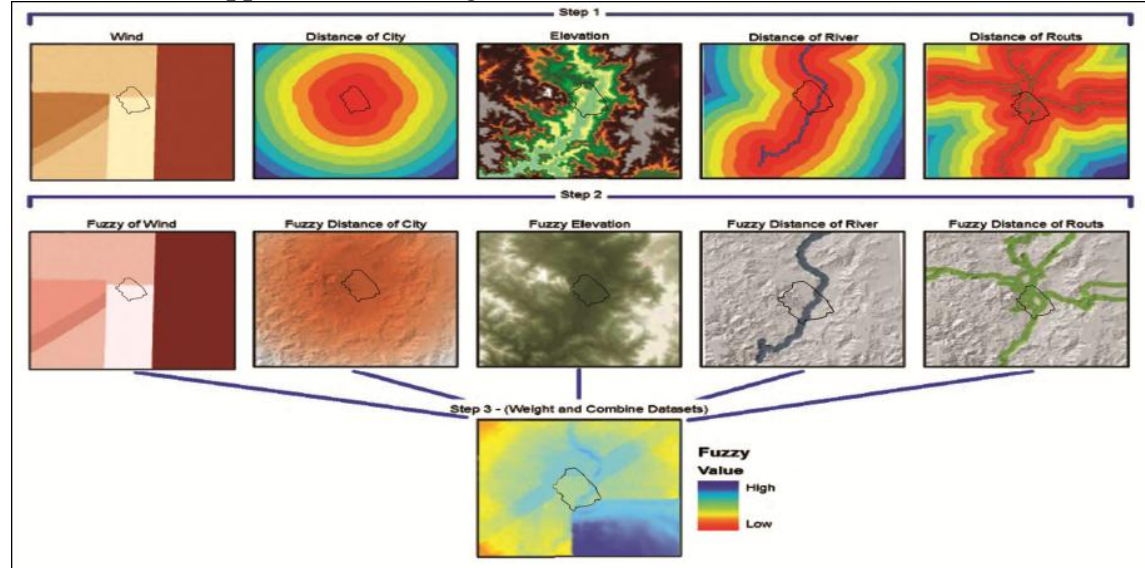

Fig. 4. Diagram of establish stages Index Overlay Method on the basis of Fuzzy Logic 
Application of GIS Models in Site selection of waste disposal in Urban Area

Therefore, before the integration of data layers, they are classified on the basis of their role in disposal center sitting (See Table 5).

Table 5. Classification of data layers for integration

\begin{tabular}{|c|c|}
\hline \multirow{2}{*}{$\begin{array}{c}\text { Geographical } \\
\text { and land use }\end{array}$} & Elevation \\
\cline { 2 - 2 } & slop \\
\cline { 2 - 2 } & geology \\
\cline { 2 - 2 } $\begin{array}{c}\text { Water } \\
\text { resources }\end{array}$ & land use \\
\cline { 2 - 2 } & Underground water \\
\hline infrastructure & River \\
\cline { 2 - 2 } & Power pipe lines \\
\hline
\end{tabular}

When using 'fuzzy AND' and 'fuzzy OR' operator, only one of the parameters (factor layers) is used to define the output value, which is contrary to our intention of using all factors. Except for water resources, in other cases the operator of 'SUM' and 'Y' are used [4]. In this study, assuming that just one water resource is enough for water supply, the maps of river and water discharge were combined using OR operator. Using of 'SUM' and ' $\mathrm{Y}>0.7$ ' has an increasing effect on the results such that the resulted value is larger or equal to maximum value of the input values. Here for integrating of elevation, slope, geology and land use maps fuzzy gamma operator was applied $(\mathrm{Y}=0.88)$. Also the maps of pipeline and road were integrated using gamma operator $(\mathrm{Y}=0.7)$. At last fuzzy Algebraic Sum operator was used for final combination of fuzzy data layers. The selection of 'SUM' and ' $\mathrm{Y}$ ' operators are such that a defined ratio is resulted among the factors of Consumption Center, Water Resources, Geophysical \& land use and Infrastructure, on the basis of their characteristics and role in site selection.

\section{RESULT AND DISCUSSION}

The result of factor maps overlay is multiplied by the result of limitation maps overlay. The final integrated maps are presented in Fig 3, 4. In general, in index overlay and fuzzy logic model, $0.12 \%$ and $0.17 \%$ of the study area was selected as suitable, respectively. The majority of selected area in both of the methods was the same. In order to comparing the methods, 3 sites were selected in allowable area with high suitability in both of the methods. The result represents the relative suitability of a site between other sites in each of the methods. It also allows the user to compare the suitability of a particular site in different methods. After prioritizing the sites in each method, the sites with high suitability in both of the methods were determined as the suitable sites for disposal center construction and suitable sites are presented in Fig 5.

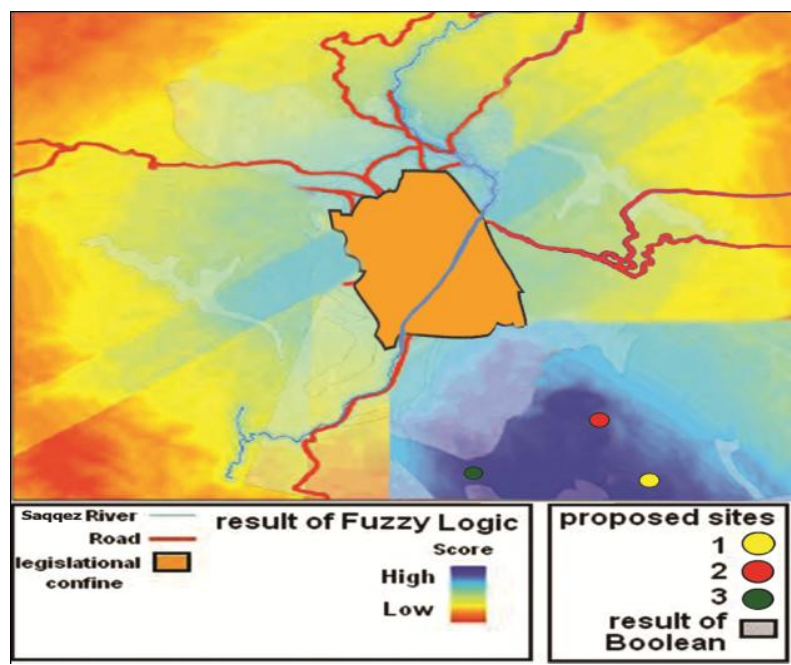

Fig.5. Suitable sites for waste disposal in Saqqez city

\section{CONCLUSION}

The final suitability index not only provides information about the optimality of the location, but also about potential problems that can affect one or more environmental components. This data is fundamental for any decision about whether or not to locate a landfill at a particular site. Based on the results obtained in our study as well as the sensitivity analysis carried out, we can conclude that Geographical Information Systems are 
a useful tool for the optimal siting of landfills. Our study shows that this instrument has the potential to assist planners, decision makers and other agents involved in the process of selecting suitable sites for municipal landfills since it increases their knowledge of the physical terrain, thus facilitating the analysis and implementation of action plans.

According to obtained results, site number 2 (close to municipal asphalt factory) with geographical location of $X=4007226$ in north width to $Y=616226$ in east length is selected as the best alternative for waste landfill in Saqqez.

Factor maps were integrated using index overlay method and fuzzy operators to determine suitable locations for disposal center building in the remaining area. In general, in index overlay and fuzzy logic model, $0.12 \%$ and $0.17 \%$ of the study area was selected as suitable, respectively. In both of the methods, the majority of suitable area was located in southeast of city, where waste demand is more than other places. Flexibility of the fuzzy method allows the user to apply a variety of data integration methods based on the characteristics of the data parts and the way they effect (support or decline) each other regarding the application [8, 14].

\section{ACKNOWLEDGEMENTS}

We are thankful to the Department of Remote sensing in Universiti Teknologi Malaysia (UTM) and International Doctorial Fellowship (IDF) for providing the facilities for this investigation.

\section{REFERENCES}

[1] B. Carter and G.F., Geographic Information System for Geoscientists: Modeling with GIS, Pergamon, Ontario, 1991, 319-470.

[2] B.Mukhopadhyay, A.Saha, N. Hazra, Knowledge Driven GIS Modeling Techniques for Copper Prospectively Mapping in Singhbhum Copper Belt, Retrospection, india,2001, 156-163.

[3] Common Disposal center Sitting Criteria, Public Service Commission of Wisconsin, 1999, www.psc.wi.gov/consumerinfo/brochures/waste/6017b.pdf

[4] K. Delaney and A. Lachapelle, "A GIS Approach to Sitting a Coal-Fired Disposal center in Franklin County, Illinois, 4, 2003, 65-76.

[5] K. H. Chi, N. W. Park, Ch.J. Chung, Fuzzy Logic Integration for Landslide Hazard Mapping Using Spatial Data from Boeun, KOREA, 3, 2001, 87-95.

[6] M.J. Valadan Zoej, M. S. Mesgari, S. Beheshtifar, M. Karimi1, Thermal Disposal center Site Selection Using GIS, Map Asia conference, 2005

[7] S. Beheshtifar, S. Mesgari, M.J. Valadan Zoej, M. Karimi, Data Integration Using Fuzzy Logic Model Application in: Power-Plant Sitting, Map India conference, 2006.

[8] K.H, Valizadeh and H. Shahabi, Comporison of Boolean,Index overlay and Fuzzy Logic Methods for data integration in hazardous material disposal center sitting, 5th international Conference on Geographic information system, 2008, Istanbul-Turkey.

[9] M. Moeinaddini, N. Khorasani, A. Danehkar, A.A. Darvishsefat, M. zienalyan,, Siting MSW landfill using weighted linear combination and analytical hierarchy process (AHP) methodology in GIS environment (case study: Karaj), Waste Management, 30, 2010, 912-920.

[10] M.A. Abdoli, Recycling of Municipal Solid Wastes. Tehran University, Iran, 2005

[11] G. Tchobanoglous and H. Theisen, S.A. Vigil., Integrated Solid Waste Management: Engineering Principles and Management Issues. McGraw-Hill,New York, USA, 1993.

[12] H. Faraji Sabokbar., Siting commercial services units with using the AHP method (case study of Torghabeh in Mashahd, Iran), Geographical Researches, 51, 2003, 125-138 (In Persian).

[13] H. Shahabi, Role of Geomorphic ingredient in Saqqez urbans surplus materials landfill site selection by using GIS models and Remote Sensing technique,. M.Sc. thesis. University of Tabriz, Iran, 2008.

[14] P.V. Gorsevski, P.E. Gessler, P. Jankowski, Integrating a fuzzy kmeans classification and a Bayesian approach for spatial prediction of landslide hazard, Journal of Geographical Systems, 5(3), 2003, 223-251. 